\title{
Daniel Welzer-Lang
}

\section{A construção do masculino: dominação das mulheres e homofobia *}

\begin{abstract}
Resumo: A partir de definições de homofobia e de heterossexismo, este artigo explora a profundidade heurística das relações sociais de sexo transversais ao conjunto de pessoas e grupos de gênero, no interior de um quadro teórico que rompe com definições naturalistas e/ ou essencialistas dos homens. O texto analisa os esquemas, o habitus, o ideal viril, homofóbico e heterossexual que constroem e fortalecem a identidade e a dominação masculina. Para desenvolver este argumento, o autor faz uma vasta revisão bibliográfica da literatura feminista francesa contemporânea.
\end{abstract}

Palavras-chove: masculinidade, homofobia, dominação, teoria feminista francesa.

Este artigo' questiona as modalidades de análise a respeito dos homens e do masculino e o quadro teórico e os instrumentos utilizados para esta análise, à luz de meus trabalhos e dos debates atuais em diferentes redes que tratam deste tema. Apoio-me, em particular, no trabalho de síntese que realizei para o exame de habilitação em orientação² e nos debates que atravessam a Rede Européia de Homens Pró-feministas e a Universidade euromediterrânea das homossexualidades. ${ }^{3}$ Este artigo completa as análises teóricas que publiquei em 1994 que definiam, entre outras coisas, o heterossexismo, a homofobia e suas ligações com a dominação masculina.

As relações homens/mulheres e homens/homens, analisadas aqui como relações sociais de sexo, parecem ser em todos os casos - hipótese que eu defendo - o produto de um duplo paradigma naturalista:

- a pseudo natureza superior dos homens, que remete à dominação masculina, ao sexismo e às fronteiras rígidas e intransponíveis entre os gêneros masculino e feminino;

- a visão heterossexuada do mundo na qual a sexualidade considerada como "normal" e "natural" está limitada às relações sexuais entre homens e mulheres. As outras sexualidades, homossexualidades, bissexualidades, sexualidades transexuais... são, no máximo, definidas, ou melhor, admitidas, como "diferentes".

\footnotetext{
* Excepcionalmente neste artigo, as notas, em virtude de sua extensão, estão editadas ao final do texto.
} 


\section{A dominação masculina e as relações homens/mulheres}

A existência da dominação masculina se tornou hoje uma evidência, inclusive na sociologia. A época de minha defesa de tese, onde era vista pelos membros da banca como uma fantasia "arqueo-paleo-marxista" (retomando uma expressão utilizada na defesa), parece longe. Numerosos colegas, inclusive homens sociólogos, utilizam hoje este paradigma para descrever o social de maneira compreensiva. ${ }^{4} \mathrm{E}$ a contribuição dos estudos feministas para afinar e enriquecer esta análise ${ }^{5}$ está hoje integrada em numeros textos. É assim que parece haver atualmente um consenso para designar as relações homens/ mulheres como relações sociais de sexo. Dito de outra forma, a dominação não deve ser analisada como um bloco monolítico onde tudo está dado, onde as relações se reproduzem ao idêntico. ${ }^{6}$ Mas a análise, tanto global quanto a que se interessa por um campo específico ou por interações particulares, deve articular o quadro global, societário (a dominação masculina), e as lutas objetivas ou subjetivas das mulheres e de seus aliados que visam a transformar as relações sociais de sexo, logo a modificar a dominação masculina.

Os homens dominam coletiva e individualmente as mulheres. Esta dominação se exerce na esfera privada ou pública e atribui aos homens privilégios materiais, culturais e simbólicos. Um setor dos estudos feministas atuais tende, aliás, a quantificar estes privilégios e a mostrar concretamente os efeitos da dominação masculina. ${ }^{7}$ A política atual, que, em nossa sociedade, visa a diminuir as "desigualdades", não deve nos deixar esquecer que elas perduram, sob pena de tomarmos nossos sonhos por realidade e não compreendermos mais nada.

Eu digo desigualdades por simplificação, mas duvidemos deste termo. Ele tende a nos mostrar as situações de homens e mulheres como resultados neutros de um sistema global, em que cada grupo de sexo, cada gênero, seria simétrico e igual na análise. E em que o sistema nos seria imposto sem possibilidades de mudanças. Mas isso não é nada. $A$ opressão das mulheres pelos homens é um sistema dinâmico no qual as desigualdades vividas pelas mulheres são os efeitos das vantagens dadas aos homens. Quando se atribui ao dividir uma torta sete partes aos homens e uma às mulheres, a luta por igualdade deve significar que se divida a torta em porções iguais. Logo, os homens terão menos!

Certamente, esta análise deve se articular com outras relações sociais, em especial as divisões hierárquicas ligadas às pertinências de classes sociais, aos grupos étnicos, à idade. Nossas vidas, nossas situações materiais são o produto de um conjunto de relações sociais.

Além disso, como outros autores, ${ }^{8}$ mostrei a assimetria que provoca a dominação dos homens. Não somente homens e mulheres não percebem da mesma maneira os fenômenos, que são no entanto designados pelas mesmas palavras, ${ }^{9}$ mas sobretudo não percebem que o conjunto do social está dividido segundo o mesmo simbólico que atribui aos homens e ao masculino as funções nobres e às mulheres e ao feminino as tarefas e funções afetadas de pouco valor. Esta divisão do mundo, esta cosmogonia baseada sobre o gênero, mantém-se e é regulada por violências: violências múltiplas e variadas as quais - das violências masculinas domésticas aos estupros de guerra, passando pelas violências no trabalho - tendem a preservar os poderes que se atribuem coletivamente $e$ individualmente os homens à custa das mulheres.

Tudo isso é conhecido, e mesmo que pendurem os debates - sobre a natureza das violências, ${ }^{10}$ as relações entre a divisão por sexo e por gênero, ${ }^{11}$ o lugar dos homens, a análise das transformações atuais, ${ }^{12}$ etc. - surge um consenso para designar a divisão entre dois grupos (ou classes) de sexo, em gêneros, como fundadora da dominação masculina. 
Já há várias décadas, inicialmente as mulheres e depois alguns homens, têm lutado e/ou produzido análises que procuram dar visibilidade e explicar esses fenômenos. Podemos nos remeter aos textos que há muito tempo servem de base a essas análises, produzidos por Christine Delphy, Colette Guillaumin, Nicole-Claude Mathieu e Paola Tabet. ${ }^{13}$ Cada uma, à sua maneira, mostra como a dominação é apresentada como óbvia, como um fenômeno natural, integrado de algum modo à divisão social e hierarquica por sexo. Da análise crítica da opressão das mulheres, nasceram as lutas contra o sexismo, o patriarcado e o viriarcado. ${ }^{14}$

\section{A dominação masculina $\theta$ as relações homens/homens}

Se hoje se admite a dominação masculina e as relações sociais de sexo têm sido utilizadas para descrevê-la, estas são freqüentemente citadas como relações sociais 'entre' os sexos, entre homens e mulheres. Essa divisão naturalista e essencialista se reproduz na própria análise. Desde 1994 (Welzer-Lang, Dutey, Dorais, 1994), mostramos como o grupo de homens é também estruturado pelos mesmos processos. Descrevi como a educação dos meninos nos lugares monossexuados (pátios de colégios, clubes esportivos, cafés..., mas mais globalmente o conjunto de lugares aos quais os homens se atribuem a exclusividade de uso e/ou de presença) estrutura o masculino de maneira paradoxal e inculca nos pequenos homens a idéia de que, para ser um (verdadeiro) homem, eles devem combater os aspectos que poderiam fazê-los serem associados às mulheres. Eu propus, referindo-me aos trabalhos de Maurice Godelier (1982), nomear o conjunto desses lugares e espaços como a "casa dos homens". Não seria demais retomar em parte aqui o que eu descrevia na época, à luz de nosso estudo sobre a homofobia.

\section{A casa-dos-homens}

Em nossas sociedades, quando as crianças do sexo masculino deixam, de certo modo, o mundo das mulheres, ${ }^{15}$ quando começam a se reagrupar com outros meninos de sua idade, elas atravessam uma fase de homossociabilidade ${ }^{16}$ na qual emergem fortes tendências e/ou grandes pressões para viver momentos de homossexualidade. Competições de pintos, maratonas de punhetas (masturbação), brincar de quem mija (urina) o mais longe, excitações sexuais coletivas a partir de pornografia olhada em grupo, ou mesmo atualmente em frente às strip-poker eletrônicas, em que o jogo consiste em tirar a roupa das mulheres... Escondidos do olhar das mulheres e dos homens de outras gerações, os pequenos homens se iniciam mutuamente nos jogos do erotismo. Eles utilizam para isso estratégias e perguntas (o tamanho do pênis, as capacidades sexuais) legadas pelas gerações precedentes. Eles aprendem e reproduzem os mesmos modelos sexuais, tanto pela forma de aproximação quanto pela forma de expressão do desejo.

Nessa casa dos homens, a cada idade da vida, a cada etapa de construção do masculino, em suma está relacionada uma peça, um quarto, um café ou um estádio. Ou seja, um lugar onde a homossociabilidade pode ser vivida e experimentada em grupos de pares. Nesses grupos, os mais velhos, aqueles que já foram iniciados por outros, mostram, corrigem e modelizam os que buscam o acesso à virilidade. Uma vez que se abandona a primeira peça, cada homem se torna ao mesmo tempo iniciado e iniciador.

Sobre este tema, os trabalhos do antropólogo Maurice Godelier sobre os Baruya da Nova Guiné ${ }^{17}$ descrevem como "o esperma é a vida, a força, o alimento que dá força à vida". Ele mostra como, no segredo da casa-dos-homens, ${ }^{18}$ os jovens homens ainda não casados e os iniciados transmitem, pela ingestão de esperma (felação), os rudimentos da dominação das mulheres. Qualquer violação desse segredo é punida muito severamente e aqueles que resistem à iniciação são obrigados por força a fazê-la, diz o pesquisador. ${ }^{19}$ 


\section{Aprender a sofrer para ser um homem, a aceltar a lel dos maiores}

Aprender a estar com os homens, ou nas primeiras aprendizagens esportivas na entrada da casa-dos-homens, a estar com os postulantes ao status de homem, obriga o menino a aceitar a lei dos maiores, dos antigos: daqueles que lhe ensinam as regras e o savoir-faire, o saber ser homem. A maneira pela qual alguns homens se lembram dessa época e a emoção que transparece então parecem indicar que esses períodos constituem uma forma de rito de passagem.

Aprender a jogar hockey, futebol ou base-ball é inicialmente uma maneira de dizer: eu quero ser como os outros rapazes. Eu quero ser um homem e portanto eu quero me distinguir do oposto (ser uma mulher). Eu quero me dissociar do mundo das mulheres e das crianças. $^{20}$

É também aprender a respeitar os códigos, os ritos que se tornam então operadores hierárquicos. Integrar códigos e ritos, que no esporte são as regras, obriga a integrar corporalmente (incorporar) os não-ditos. Um desses não-ditos, que alguns anos mais tarde relatam os rapazes já tornados homens, é que essa aprendizagem se faz no sofrimento. Sofrimentos psíquicos de não conseguir jogar tão bem quanto os outros. Sofrimentos dos corpos que devem endurecer para poder jogar corretamente. Os pés, as mãos, os músculos... se formam, se modelam, se rigidificam por uma espécie de jogo sadomasoquista com a dor. O pequeno homem deve aprender a aceitar o sofrimento - sem dizer uma palavra e sem "amaldiçoar" - para integrar o círculo restrito dos homens. Nesses grupos monossexuados se incorporam gestos, movimentos, reações masculinas, todo o capital de atitudes que contribuirão para se tornar um homem.

Nos primeiros grupos de meninos, se "entra" em luta dita amigável (não tão amigável assim se acreditamos no monte de choros, de decepções, de tristezas escondidas que se associam a eles) para estar no mesmo nível que os outros e depois para ser o melhor. Para ganhar o direito de estar com os homens ou para ser como os outros homens. Para os homens, como para as mulheres, a educação se faz por mimetismo. Ora, o mimetismo dos homens é um mimetismo de violências. De violência inicialmente contra si mesmo. A guerra que os homens empreendem em seus próprios corpos é inicialmente uma guerra contra eles mesmos. Depois, numa segunda etapa, é uma guerra com os outros.

Articulando prazeres - prazer de estar entre homens (ou homens em formação) e se distinguir das mulheres, prazer de poder legitimamente fazer "como os outros homens" (mimetismo) - e dores do corpo, cada homem vai individualmente e coletivamente fazer sua iniciação. Através dessa iniciação se aprende a sexualidade. A mensagem dominante: ser homem é ser diferente do outro, diferente de uma mulher. Além disso, eu mostrei como a "primeira peça" da casa-dos-homens, o que eu chamei de vestíbulo da "gaiola da virilidade", é um lugar de alto risco de abuso. Ela funciona, parece, como um lugar de passagem obrigatório que é fortemente freqüentado. Um corredor onde circulam, ao mesmo tempo, jovens recrutas da masculinidade (os pequenos homens que acabaram de abandonar a saia das mães) ${ }^{21}$ e outros pequenos homens recém-iniciados que vêm também - assim é o costume dessa casa - transmitir uma parte de seus saberes e seus gestos. Mas a antecâmara da casa-dos-homens é também um lugar freqüentado periodicamente por homens mais velhos. Homens que ocupam, ao mesmo tempo, o lugar de irmão mais velho, modelo masculino a ser conquistado pelos pequenos homens e agentes encarregados de controlar a transmissão dos valores. Alguns se nomeiam pedagogos, outros monitores de esporte, ou ainda padres, chefes de escoteiros... Alguns estão presentes fisicamente. Outros agem através de suas mensagens sonoras, de suas imagens que se manifestam nesse lugar. Outros ainda são denominados artistas, cantores, 
poetas. De fato, falar da "primeira peça" da casa-dos-homens constitui uma forma de abuso de linguagem. Dever-se-ia dizer: as primeiras peças, pois a geografia das casasdos-homens é muito mutável. A cada cultura ou a cada microcultura, às vezes em cada cidade ou vilarejo, a cada classe social, corresponde uma forma de casa-dos-homens. $O$ tema da iniciação dos homens se conjuga de maneira extremamente variável. O conceito é constante, mas as formas são lábeis.

O masculino é, ao mesmo tempo, submissão ao modelo e obtenção de privilégios do modelo. Alguns homens mais velhos se aproveitam da credulidade dos novos recrutas e essa primeira peça da casa é vivida por numerosos meninos como a antecâmara do abuso. E isso numa proporção que, à primeira vista, pode surpreender. ${ }^{22}$ Não somente o pequeno homem começa a descobrir que, para ser viril, é preciso sofrer, mas também nessa peça (ou nas outras, não se trata aqui de uma metáfora) o menino é, às vezes, iniciado sexualmente por um adulto. Iniciado sexualmente pode também significar violado. Ser obrigado - sob obrigação ou ameaça - de acariciar... de chupar ou de ser penetrado de maneira anal por um sexo ou um objeto qualquer. Masturbar o outro. Deixar-se acariciar... Compreende-se que os homens a quem uma tal iniciação é imposta guardem seguidamente marcas indeléveis.

Tudo parece indicar, de acordo com as entrevistas realizadas no estudo sobre a homofobia e depois no das prisões, ${ }^{23}$ que muitos homens que foram violentados sexualmente por outro homem mais velho acabam por reproduzir esta forma particular de abuso. É como se eles se repetissem: "Já que eu passei por isso, que ele também passe". E o abuso, além dos beneficios que traz, é também uma forma de exorcismo, uma conjuração da desgraça vivida anteriormente. Depois, ao longo dos anos, quando a lembrança da dor e da humilhação se estanca um pouco, o abuso inicial funcionaria como um elemento de compensação, um pouco como uma conta bancária que teria sido aberta por imposição; onde os outros abusos perpetrados representariam os juros que o homem abusado vem cobrar. Isso vale tanto para abusos realizados contra homens como os contra mulheres, realizados em outros lugares.

Outros se fecham em uma couraça, incorporando, de uma vez por todas, ${ }^{24}$ que a competição entre homens é uma selva perigosa onde é necessário saber se esconder, se debater e onde in fine a melhor defesa é o ataque.

Eu evoco aqui os abusos (ditos) sexuais. ${ }^{25}$ Eles são bem reais e em número muito importante. As pesquisas futuras nos revelarão as formas, a freqüência e os efeitos a curto, médio e longo prazo. ${ }^{26}$ Confessemos por enquanto nossa negligência sobre esse tema. Outras formas de abuso - freqüentemente suas próprias preliminares - são cotidianas, complementares ou paralelas aos abusos sexuais. Abusos individuais, mas também abusos coletivos. Que se pense nos diferentes golpes: socos, pontapés, empurrões. As pseudobrigas nas quais, na realidade, o maior mostra sua superioridade física para impor seus desejos. As ofensas, o roubo, a ameaça, a gozação, o controle, a pressão psicológica para que o pequeno homem obedeça e ceda às injunções e aos desejos dos outros... Há um conjunto multiforme de abusos de confiança violentos, de apropriação do território pessoal, de estigmatização de qualquer coisa que se afaste do modelo masculino dito correto. Todas as formas de violência e de abuso que cada homem vai conhecer, seja como agressor, seja como vítima. Pequeno, fraco, o menino é uma vítima marcada. Protegido por seus colegas, ele pode agora fazer os outros sofrerem o que ele tem ainda medo de sofrer. Exorcizar o medo agredindo o outro e gozar dos benefícios do poder sobre o outro é a máxima que parece estar inscrita no frontal de todas essas peças.

Não nos enganemos. Essa união que faz a força, esta aprendizagem do coletivo, da solidariedade, da fraternidade - os homens de um mesmo grupo podem ser associados 
a irmãos - não tem apenas seus lados negativos. A solidariedade masculina intervém para evitar a dor de ser uma vítima; essa casa-dos-homens é o lugar de transmissão de valores positivos. Ter prazer juntos, descobrir o interesse do coletivo sobre o individual, são valores que fundam a solidariedade humana.

É verdade que na socialização masculina, para ser um homem, é necessário não ser associado a uma mulher. O feminino se torna até o pólo de rejeição central, o inimigo interior que deve ser combatido sob pena de ser também assimilado a uma mulher e ser (mal) tratado como tal.

Estaríamos enganados se limitássemos a análise da casa-dos-homens à socialização infantil ou juvenil. Mesmo adulto, casado, o homem, ao mesmo tempo que "assume" o lugar de provedor, de pai que dirige a família, de marido que sabe o que é bom e correto para a mulher e as crianças, continua a freqüentar peças da casa-dos-homens: os cafés, os clubes, até mesmo as vezes a prisão, onde é necessário sempre se distinguir dos fracos, das femeazinhas, dos "veados", ou seja, daqueles que podem ser considerados como não-homens.

Os trabalhos de Christophe Dejours (1998) e Pascale Molinier (1997)27 mostram como a virilidade, além dos benefícios (privilégios) que ela traz aos homens, é também uma estratégia de resistência para lutar contra o medo, o nojo que inspira o "trabalho sujo" (dos operários da construção civil ou dos empresários encarregados de demitir, por exemplo), e também como a virilidade só pode ser vivida transversalmente em relação às esferas públicas e privadas.

O masculino, as relações entre homens são estruturadas na imagem hierarquizada das relações homens/mulheres. Aqueles que não podem provar que "têm" 28 são ameaçados de serem desclassificados e considerados como os dominados, como as mulheres. Dir-se-á deles que "eles são como elas" . É assim que na prisão um segmento particular da casa-dos-homens, os jovens homens, os homens localizados ou designados como homossexuais (homens ditos afeminados, travestis...), homens que se recusam a lutar, ou também os que estupraram as mulheres, dominadas, ${ }^{29}$ são tratados como mulheres, violentados sexualmente pelos "grandes homens" que são os chefões do tráfico, roubados, ${ }^{30}$ violentados. Freqüentemente, eles são apenas colocados na posição da "empregada" e devem assumir o serviço daqueles que os controlam, particularmente o trabalho doméstico (limpeza da célula, da roupa...) e os serviços sexuais.

As relações sociais de sexo se exercem de maneira transversal ao conjunto da sociedade, fazendo com que homens e mulheres sejam atravessados/as por elas.

É então nessa perspectiva que eu propus que se definisse a homofobia como a discriminação contra as pessoas que mostram, ou a quem se atribui, algumas qualidades (ou defeitos) atribuídos ao outro gênero. A homofobia engessa as fronteiras do gênero.

Quando, com Pierre Dutey, foram interrogadas umas 500 pessoas sobre a forma como elas reconheciam pessoas homossexuais na rua, na sua grande maioria, elas falam de homens homossexuais (o lesbianismo é invisível). E mais, elas associam aos homossexuais os homens que apresentam sinais de feminilidade (voz, roupas, jeito corporal). Os homens que não mostram sinais redundantes de virilidade são associados às mulheres e/ou a seus equivalentes simbólicos: os homossexuais.

O paradigma naturalista da dominação masculina divide homens e mulheres em grupos hierárquicos, dá privilégios aos homens à custa das mulheres. E em relação aos homens tentados, por diferentes razões, de não reproduzir esta divisão (ou, o que é pior, de recusá-la para si próprios), a dominação masculina produz homofobia para que, com ameaças, os homens se calquem sobre os esquemas ditos normais da virilidade. 


\section{Os "Grandes homens"}

Acabo de falar dos chefões do tráfico na prisão e denominá-los como "Grandes homens". É possível que a influência da análise marxista que privilegiou as classes sociais, ou da feminista pós-marxista que nos fez adotar uma análise análoga para estudar a dominação masculina, ${ }^{31}$ acrescida dos poucos estudos sobre os homens e o masculino, tenham ocultado o que cada homem sabe. Mesmo sendo um homem, um dominante, todo homem está também submetido às hierarquias masculinas. Nem todos os homens têm o mesmo poder ou os mesmos privilégios. Alguns, que eu qualifico de "Grandes-homens", têm privilégios que se exercem à custa das mulheres (como todos os homens) mas também à custa dos homens. A análise transversal das relações sociais de sexo abre outras pistas de análise e de reflexão que me parecem importantes e que eu gostaria de aprofundar.

Utilizei a metáfora/conceito da casa-dos-homens para descrever a socialização masculina. Mas, por enquanto, não abordei a estruturação funcional do masculino. Quem são os "Grandes-homens"? Como seu status é retribuído? Em dinheiro, honra (confortando a virilidade, como diz Pierre Bourdieu) e status de poder.

Empiricamente (ver meus estudos sobre a troca de casais e o comércio do sexo), ${ }^{32}$ sabe-se que, para um homem, o fato de ser visto com "belas" mulheres classifica-o como "Grande-homem", o que também acontece com aquele que tem dinheiro e/ou poder manifesto sobre homens e mulheres. Todos os homem que aceitam os códigos de virilidade têm ou podem ter poder sobre as mulheres (o que ainda deve ser quantificado); alguns entre estes (chefes, Grandes-homens de todos os tipos) têm também poder sobre os homens. É verdadeiramente neste duplo poder que se estruturam as hierarquias masculinas.

Pode-se, deve-se articular também estas divisões com as classes sociais. Um/a chefe, um/a patrão/patroa tem - de fato - poder no espaço profissional sobre outros homens e outras mulheres. Sem dúvida - ver também os trabalhos das sociólogas feministas e os de François de Singly - não é indiferente ser homem ou mulher neste momento. Falta ainda estudar as relações entre poderes profissionais e poderes (e privilégios) domésticos. Mas tudo isso ainda é muito abstrato.

O portal de entrada "Grandes Homens" oferece também outros meios para estudar a distribuição dos poderes masculinos sobre as mulheres e os homens. Tomemos o exemplo dos legionários. ${ }^{33}$ Quando eles voltam de ações no exterior, Ihes são permitidas algumas liberdades como trazer álcool e mulheres. Todos ou alguns ${ }^{34}$ têm direito a "trazer mulheres na sua bagagem". ${ }^{35}$ Essas mulheres imigrantes, na maior parte das vezes ilegais, que em geral nem falam francês (muitas são inclusive analfabetas), tornam-se então dependentes dos guerreiros que as trouxeram consigo. "É necessário compreender que os legionários são desembarcados em qualquer lugar do mundo, com a ordem: 'Matem!' Por isso que a gente dá para eles algumas liberdades depois...", disse-me um oficial do exército. Essas mulheres (ou rapazes), oriundas de países pobres, são um privilégio associado ao status de guerreiro pós-colonial.

Na região onde vivem esses legionários, segundo nossas informantes - fato que se pode verificar de maneira mais empírica examinando as queixas nos serviços telefônicos de ajuda a mulheres vítimas de violência -, os homens de armas (legionários, mas também policiais...) parecem concentrar mais as queixas das mulheres sobre suas práticas domésticas do que outros homens. Em todo caso, porque eles têm uma arma em casa, eles são mais assassinos. São portanto as mulheres que pagam o preço dos privilégios masculinos.

Seria necessário sem dúvida montar um quadro demonstrativo para saber quem são os "Grandes-homens" e como se distribuem os poderes masculinos, inclusive entre 
"Grandes-homens". Utilizando os trabalhos de Maurice Godelier, e adaptando-os a nossas sociedades, pode-se distinguir entre os "Grandes-homens" aqueles que têm um poder político, religioso (ou mágico), econômico, guerreiro, administrativo, científico, universitário... e pôr na balança esse poder, instituído e instituinte, com os privilégios que obtêm esses homens de suas funções nas relações com as mulheres e com os homens. Depois, como faz Maurice Godelier ao comparar a situação pré-colonial, colonização e pós-colonialismo, poderiam ser estudadas as evoluções que vivem, ou viveram, os "Grandes-homens" (transformação das funções e dos poderes, influência da presença de homens e mulheres em alguns cargos, desaparecimento ou reconversão deles). Em todo caso, é uma pista de pesquisa que me parece fecunda.

Essa questão é importante no estudo das mudanças masculinas. Alguns homens desempregados, ${ }^{36}$ mesmo permanecendo homens em suas relações com as mulheres, seguem uma mobilidade social que os faz aproximarem-se seriamente da situação de exclusão, de precariedade de algumas mulheres. No entanto, outras mulheres, em mobilidade ascendente, tendem a copiar os esquemas de concorrência viril dos homens.

O que esconde, em última instância, a análise naturalista da divisão social do gênero são a historicidade e a contingência dessa divisão. É provável que, na seqüência das lutas feministas e na evolução por igualitarismo de nossas sociedades, ela se torne obsoleta, ${ }^{37}$ podendo inclusive ser trocada por outras formas de dominação entre humanos/ nas.

Mas a dominação masculina não é o único paradigma que condiciona nossas representações e nossas práticas. Vamos a seguir tratar da heterossexualidade.

\section{A heterossexualidade: um quadro naturalista para dividir homens e mulheres}

Há uma dupla análise na história recente das idéias na França, particularmente daquelas que criticam as construções sociais do gênero masculino e/ou das sexualidades masculinas. De um lado temos os trabalhos situados nas ou em volta das correntes feministas, que privilegiam a análise das relações sociais de sexo e a dominação masculina. Do outro lado temos escritos, inspirados em Michel Foucault, ${ }^{38}$ de historiadores como Philippe Ariès ${ }^{39}$ e Jean-Louis Flandrin ${ }^{40}$ que põem em suspeição o quadro heterossexuado da normatividade masculina.

Ler-se-á com interesse 0 texto de Jean-Yves Le Talec ${ }^{41}$ lembrando as análises foucaultianas sobre a novidade do conceito de homossexualidade. A categoria "homossexual" (não a prática designada nesta categoria) é recente. Eé porque as ciências médicas designam uma categoria desviante que se pode, em seguida, criar seu corolário: a heterossexualidade. Homo/hetero, como homem/mulher, são os pares de oposição que só adquirem sentido quando tomados juntos.

O surgimento do sciencia sexualis, ${ }^{42}$ a definição dos indivíduos não mais através de um dado fisiológico (o aparelho genital), mas através de uma categoria psicológica que é o desejo sexual, contribuiu para impor nos homens ${ }^{43}$ um quadro heterossexual apresentado, ele também como uma forma natural de sexualidade. Assimilando a sexualidade, e seu bloco de jogos, de desejos, de prazeres da reprodução humana, o paradigma heterossexual se impôs como linha de conduta para os homens.

É o que fundamenta hoje o heterossexismo. O heterossexismo - e aqui eu adoto uma definição americana - é a discriminação e a opressão baseadas em uma distinção feita a propósito da orientação sexual. O heterossexismo é a promoção incessante, pelas instituições e/ou indivíduos, da superioridade da heterossexualidade e da subordinação 
simulada da homossexualidade. O heterossexismo toma como dado que todo mundo é heterossexual, salvo opinião em contrário. ${ }^{43}$

Mas estaríamos enganados se limitássemos esse quadro de exclusão que cria o heterossexismo apenas à homossexualidade. Toda forma reivindicada de sexualidade que se distingue da heterossexualidade é desvalorizada e considerada como diferente da doxa de sexo que se impõe como modelo único. O mesmo acontece com a bissexualidade, as sexualidades transsexuais, etc.

Nós estamos claramente em presença de um modelo político de gestão de corpos e desejos. $\mathrm{E}$ os homens que querem viver sexualidades não-heterocentradas são estigmatizados como não sendo homens normais, acusados de serem "passivos", e ameaçados de serem associados a mulheres e tratados como elas. Pois se trata bem disto, ser homem corresponde ao fato de ser ativo.E não foi por acaso que encontramos os estupradores dos homens, ${ }^{45}$ pois ativos e penetrantes não vivem como homossexuais. Michäel Pollack menciona o mesmo na obra Les homosexuels et le sida. Ele evoca "a hierarquia tradicionalmente estabelecida [...] entre o "fodido" e o "fodedor", o primeiro sendo recriminado socialmente pois ele transgride a ordem "natural" das coisas, organizada segundo a dualidade feminino (dominado) e masculino (dominante). De forma que, em algumas culturas, só é considerado um "verdadeiro veado" aquele que se deixa penetrar e não aquele que "penetra". ${ }^{46}$

Aqui também o heterocentrismo constitui categorias. Ele distingue os dominantes, que são os homens ativos, penetrantes, e os outros, aquelas e aqueles que são penetradas/ os, logo dominadas/os. ${ }^{47} \mathrm{E}$ é claramente a homofobia que se aplica àqueles, homossexuais, bissexuais, transsexuais, desvalorizando-os porque eles/elas não adotam, ou são suspeitos de não adotar, configurações sexuais naturais.

Num primeiro momento, em 1994, eu propus que se qualificasse de "homofobia particular" o estigma que se aplicava aos homossexuais assumidos: aqueles que, podendo ou não ser reconhecidos, têm a cara de pau de reivindicar essa prática decretada anormal. ${ }^{48}$ Não se tratava de um erro, mas de uma análise incompleta que subestimava o paradigma heterossexista.

De fato, o duplo paradigma naturalista que define, por um lado, a superioridade masculina sobre as mulheres e, por outro lado, normatiza o que deve ser a sexualidade masculina produz uma norma política andro-heterocentrada e homofóbica que nos diz o que deve ser o verdadeiro homem, o homem normal. Este homem viril na apresentação pessoal e em suas práticas, logo não afeminado, ativo, dominante, pode aspirar a privilégios do gênero. Os outros, aqueles que se distinguem por uma razão ou outra, por sua aparência, ou seus gostos sexuais por homens, representam uma forma de não-submissão ao gênero, à normatividade heterossexual, à doxa de sexo ${ }^{49}$ e são simbolicamente excluídos do grupo dos homens, por pertencerem aos "outros", ao grupo dos dominados/as que compreende mulheres, crianças e qualquer pessoa que não seja um homem normal.

Encontra-se aqui uma análise de Nicole-Claude Mathieu que vê o masculino como quadro geral, normal, e o feminino como uma especificidade particularista que constitui toda prática social que se distingue da norma.

Nas ciências sociais, como no senso comum, a análise que prevalece é heterocentrista. Na melhor das hipóteses, hoje, como conseqüência das lutas que visibilizam a homossexualidade e da aparente compaixão provocada pela homossexualização da AIDS (Defert, 1990), vemos aparecer um "heterossexismo diferencialista", uma "tolerância opressiva", diz Altman (1993), que aceita o fato de que existam seres diferentes, os/as homossexuais, e, por conseqüência, é normal, progressista, lhes dar alguns direitos. ${ }^{50}$ Os debates recentes, e certamente ainda presentes no momento da publicação deste texto, 
sobre a homoparentalidade ${ }^{51}$ (nos) mostram os limites objetivos dessa análise naturalista diferencialista. Desprezando-se análises antropológicas que mostram como a reprodução humana e a parentalidade são fenômenos manipulados socialmente para reforçar a dominação masculina, ${ }^{52}$ a reprodução humana é naturalizada no modelo do casal homem/ mulher. Em cena as mães e os pais solteiros, os - já - pais homossexuais, as procriações medicalmente assistidas... Em cena também as culturas matrilineares onde o genitor pouco importa. "A" família é apresentada não mais como uma forma social evolutiva, mas como um quadro natural que liga um homem e uma mulher. ${ }^{53}$ Quer seja a respeito do androcentrismo e do esquecimento das mulheres nas análises, quer seja a respeito das práticas não-heterocentradas, as ciências sociais deverão, sem dúvida, desenvolver uma ruptura epistemológica nos anos que virão: elas têm, em todo caso, a obrigação de pedir desculpas.

\section{As lutas contra as políticas do macho}

Por razões históricas, as lutas dos homens contra a dominação masculina e as lutas para criticar o heterossexismo foram duas realidades sociais dissociadas. Cada paradigma naturalista cria e reproduz seu sistema próprio hierárquico de classificação no qual a homofobia divide, segmenta em oposições binárias, aqueles que parecem se adequar ao perfil do dominante e os outros. Se é homem ou mulher, macho ou hetero (diz-se geralmente 'normal'), ou outro.

Os movimentos sociais reproduziram essa divisão nos homens. De um lado, após o ano de $1975,{ }^{54}$ apareceram grupos de homens anti-sexistas que discutiam suas relações com as mulheres, sexuais ou não, e implicitamente afirmavam suas certezas heterossexuais. Esses mesmos homens, alguns anos mais tarde, se definiram na França e na Europa como pró-feministas. O termo pró-feminista foi adotado consensualmente entre os homens e as mulheres presentes no colóquio do GREMF em 1996 no Québec e buscava agrupar esses homens que se denominavam de anti-sexistas, masculinistas, ${ }^{55}$ marcar a solidariedade dos homens com as análises feministas e respeitar a autonomia do movimento das mulheres, deixando a elas a exclusividade do termo feminista. Ele marca também uma ruptura importante. Os homens pró-feministas se reconhecem como pessoas construídas socialmente como homens, logo como dominantes em relação às mulheres. Sua existência questiona a capacidade de alianças e de análises comuns entre homens e mulheres, dominantes e dominados. O pró-feminismo europeu problematizou ao mesmo tempo a opressão das mulheres e a alienação dos homens dominantes.

Outros grupos de homens apareceram no que podemos qualificar de nebulosa anti-sexista. Encontram-se aí numerosos grupos que aceitam total ou parcialmente aquilo que o feminismo pôs em dúvida. Alguns grupos influenciados por Robert Bly e pelo New Age reontologizam o masculino e o feminino e buscam a masculinidade tradicional através de arquétipos e sonhos. Presentes sobretudo na América do Norte, outros grupos se centraram no atendimento aos homens violentos. Quanto às Redes Homens no Québec ou Redes Homens na França, Suíça e Bélgica, lançadas pelo psicanalista Guy Corneau, elas oscilam entre uma vontade de compreender a alienação masculina produzida pelas relações sociais de sexo e pela dominação masculina e uma influência dos movimentos de desenvolvimento pessoal. Aproveitando-se da popularidade de Guy Corneau, elas agrupam homens muito diversos, desde jovens homens à procura de novas figuras de militantismo a homens marcados pela vida. O mérito dessas redes é o de acompanhar as mudanças massivas que estão acontecendo da parte dos homens. E não é utópico prever, sob uma forma ou outra de institucionalização, estruturas que ajudem os homens que, 
confrontados com a inadequação entre construção social do masculino e (novas) exigências das mulheres, necessitem de apoio.

Enfim, em volta dos movimentos squats e de diferentes agrupamentos libertários e antifacistas, criaram-se ultimamente vários coletivos anti-sexistas (Nantes, Lille, Paris, Lyon, Montpellier...), que reproblematizam - de maneira mista ou não - as lutas contra o sexismo, a homofobia e a lesbofobia. Um deles está representado nas análises da revista Star. ${ }^{56}$

Por outro lado, e em espaços distintos dos primeiros, nós vimos homens que, do FHAR (Front Homosexuel d'Action Revolucionaire, um movimento criado por mulheres) às lutas sobre o PaCS, passando pela anulação das leis restritivas contra a homossexualidade, ${ }^{57}$ lutaram contra a heteronormatividade e seus efeitos discriminatórios. Como grupo dominado, os homossexuais masculinos colocaram em evidência as condições de opressão: repressão em numerosos países, inclusive na França, direitos distintos dos outros homens dando a impressão de serem considerados como cidadãos de segunda ordem, agressões no espaço público, invisibillidade nos livros escolares contribuindo ao isolamento...

Entre as duas correntes, nada ou quase nada. ${ }^{58}$ Algumas tentativas de encontros, porém mais freqüente um grupo, dos gays, que se afirmam - com razão - dominados, recusam-se a ver que mesmo dominados eles continuam sendo homens, portanto dominantes em relação às mulheres. Do outro lado, há dominantes que dizem se assumir como tais, mas que continuaram por muito tempo a problematizar apenas a evolução das relações homens/mulheres. Ora, para ser completa, a análise crítica do masculino deve assumir a crítica do conjunto do modelo macho. $O$ fosso entre essas duas tendências críticas foi reforçado inclusive pela misoginia de alguns homens homossexuais, ou pela utilização de sátiras homofóbicas contra alguns gays afeminados (as "loucas"), que reproduzem para alguns, por jogo ou desprezo, os estereótipos da feminilidade.

Para as mulheres, a situação, sem ser idêntica - as mulheres lésbicas se definiram na sua maioria como feministas há muito tempo-, mostra também a dificuldade de articular esse duplo paradigma. Os trabalhos recentes do seminário de Toulouse "Gays, lésbicas, bissexuais, transgêneros, queers; orientação e identidades sexuais, questões de gênero" nos mostraram a complexidade das relações entre mulheres lésbicas e feministas nãolésbicas no seio do movimento das mulheres, as homossexuais tendo a impressão de terem sido seguido invisibilizadas pelas outras feministas.

E nós nos confrontamos hoje com uma falta. Uma falta para analisar as construções sociais do masculino em sua totalidade, uma falta para compreender as evoluções dos homens em suas relações com as mulheres e em suas relações com os homens.

\section{O masculino em todos os seus estados e brilhos?}

A paisagem social dos homens mudou. É certo que existem (alguns) homens progressistas ou igualitaristas que se encarregam totalmente ou em parte do trabalho doméstico, particularmente quando eles vivem sozinhos. Aqueles que lutam com as mulheres pela paridade na política, ${ }^{59}$ aqueles que confrontados ao duplo standart assimétrico do limpo e do sujo ${ }^{60}$ ou do amor tentam negociar, a qualquer preço, um entendimento igualitário com as mulheres. Há também aqueles que foram criados na mixidade e se confrontaram muito cedo com a necessidade de encontrar uma forma comum com suas amigas mulheres, algumas centenas de homens pró-feministas...

Mas essas não são as únicas transformações visíveis. Nós estamos na presença dessas novas figuras da desordem ${ }^{61}$ que parecem reinar na masculinidade: a pregnância das novas figuras de transgenders ${ }^{62}$ percebidas nos estudos sobre a prostituição, os embaralhamentos momentâneos ou contínuos ${ }^{63}$ das identidades sexuadas e sexuais 
encontradas, por exemplo por trás das telas do minitel rose, ${ }^{64}$ as centenas de SNAGs (Sensitive New Age Guys), como eles são chamados na Austrália, ${ }^{65}$ sem falar das drags queens, estes homens que se vestem de mulheres e que não se definem nem como homossexuais, nem como travestis.

Os modelos, as reivindicações e o vivido do conjunto desses homens expõem uma variedade extrema, mas eles têm em comum o fato de colocar objetivamente e/ou subjetivamente as definições homofóbicas e heterossexistas "da" masculinidade, de transgredir as definições sociais da masculinidade. As fronteiras de gênero têm a tendência, do lado dos homens, de se decompor, de explodir, e o masculino se mostra em todos os seus estados.

O que acontece? Várias hipóteses parecem interessantes para explicar essas mudanças, das quais a história nos dirá se se trata de um fenômeno passageiro ou de uma verdadeira transformação do masculino como gênero. As lutas das mulheres e o feminismo contestaram, com um sucesso importante mas nunca definitivo, a supremacia masculina. Em parte a dominação perdura, mas tendencialmente ela se pulveriza e perde sua acuidade opressiva. Ao mesmo tempo, o gênero masculino se modifica, integra outros conteúdos, outros valores. O que não quer dizer, aliás - e de longe -, que não tenha havido recomposição da dominação masculina, e que a colocação em dúvida da masculinidade seja linear ou que seja necessário esquecer a articulação entre relações sociais de sexo e estruturação em classes sociais.

Assim, como observa, com razão, François de Singly, ${ }^{66}$ deve-se desconfiar das micromudanças chamadas muito apressadamente de "revolução conjugal". Utilizando Georg Simmel, ele acrescenta: "o masculino é menos perceptível que o feminino na medida em que o primeiro pode mais facilmente disfarçar-se de interesse geral: os conteúdos culturais completamente neutros em aparência mascaram a essência masculina". ${ }^{67} \mathrm{Da}$ mesma forma, toma a virilidade e suas mudanças como exemplo:

A desvalorização da virilidade, de suas demonstrações de força psíquica, era possível na medida em que os grupos sociais mais afetados pelas lutas em torno da questão dos sexos eram as classes médias e superiores, grupos em que este capital físico e simbólico ocupava um lugar secundário na estrutura das riquezas masculinas. Tudo se passa como se a renegociação das relações entre os sexos tivesse recaído sobre as costas das camadas populares. O valor físico dos operários - sua única riqueza - assim como os valores domésticos das donas de casa populares são objeto de rejeição tanto para homens quanto para mulheres dos meios das camadas progressistas. Enquanto esses últimos sorriam ao ouvir falar de lutas sociais, histórias da carochinha, ${ }^{68}$ na verdade eles participavam dela se engajando na luta contra o antigo, contra os vestígios da força masculina (do lado masculino) ou da rotina (do lado feminino). ${ }^{69}$

De maneira concomitante, e isso se acelerou com a homossexualização da AIDS, o movimento gay contestou as bases homofóbicas do masculino e algumas hierarquias das relações entre os homens. Mesmo que os gays, como eu já indiquei, não sejam os últimos a desejar esconder o que é qualificado de feminino entre os homens, na época militante, o FHAR (e suas célebres "gasolinas"), o GLH (Grupo de Liberação Homossexual), o CUARH (Comitê de Urgência Anti-Repressão Homossexual), e hoje o comércio gay e as associações de luta contra a AIDS, visibilizaram outros modelos "da" masculinidade. É claro, aí também, as transgressões da masculinidade: essas variações do masculino não significam ipso facto que se recoloquem em causa as relações sociais de sexo (ou de gênero). Janis Raymond já havia assinalado isso a respeito das transsexuais; ${ }^{70}$ a dificuldade de alguns gays de aceitar que o que vivem algumas mulheres homossexuais seja diferente do que 
eles mesmos vivem é um outro exemplo. ${ }^{71}$ Como sublinha muito justamente Nicole-Claude Mathieu:72 "Não se sabe se existe uma categoria 'homens', pois se trata apenas do masculino".

Quando se examinam certas formas de emergência de novas figuras masculinas à luz das relações sociais de sexo, os exemplos de que não se ponham em dúvida posições de dominância masculina são numerosos. No contexto da prostituição os transgêneros têm a pretensão, enquanto homens, de saber mais que as mulheres sobre as demandas dos homens-clientes, assim como de responder melhor a elas. Alguns homens que se autodefinem como "feministas" não se incomodam de dar lições de feminismo a suas amigas ao mesmo tempo que se negam a falar deles como homens. As drags queens se dizem mais bonitas que as mulheres. Quanto aos homens do minitel, essas mulheres telemáticas, eles organizam espaços onde podem evitar as confrontações com as mulheres e acreditar que homens e mulheres tenham a mesma busca instrumental de desejos e erotismo. E, é claro, eu poderia descrever as reivindicações dos "pais divorciados" que, em alguns casos, querem controlar não sua paternidade (o que foi o caso dos militantes do ARDECOM), mas a contracepção e o direito ao aborto de sua companheira. Alguns reivindicam até uma menor credibilidade em caso de queixa feminina de estupro. Ou seja, transgredir socialmente as categorias sociais da masculinidade, pôr em dúvida a unicidade do modelo, marca sem dúvida uma crise profunda da identidade masculina confrontada com os efeitos do feminimo e das contestações gays. Isso traduz também as transformações das relações intra-gênero que podem não ter conseqüências nas relações inter-gênero, as relações sociais de sexo entre homens e mulheres.

É verdade que a contestação pelas feministas da dominação masculina fez com que alguns temessem o aparecimento de um modelo único (L'un est l'autre), da androginia indiferenciada. É justamente o contrário que aparece, no caso dos homens. Transgenders, transgêneros, drag queens, SNAG, gender fuckers... são alguns destes exemplos. Opostas à dualidade dos modelos de masculinidade e de feminilidade, as críticas masculinas do sexismo e/ou da homofobia e/ou do patriarcado/viriarcado veêm aparecer novos modelos, múltiplos, onde as lutas internas das relações sociais de sexo encontram outros espaços de debates.

\section{Alguns instrumentos para estudar essas transformações}

Como analisar essas transformações, essas flutuações, essas aparentes transgressões de modelo? Quais utensílios teóricos utilizar para saber o que nessas evoluções corresponde a verdadeiras mudanças, ou o que revela transformações cosméticas, na verdade formas de recuperação de um poder macho, heteronormatizado ou não, contestado pelas feministas?

A análise feminista e pró-feminista, particularmente a análise materialista, permite estudar o que A.M. Daune-Richard e A.M. Devreux ${ }^{73}$ chamam de "mobilidades sociais de sexo". Depois de ter feito valer o interesse do instrumento mobilidade social utilizado na análise das classes sociais, elas acrescentam a respeito das relações sociais de sexo:

Fazer funcionar um instrumento "mobilidade" que analise os processos de categorização saídos de uma relação social pressupõe não apenas se fechar em um dos campos do social mas e isto é um corolário quase obrigatório - também se fechar em categorias descritivas e mensuráveis, categorias taxinômicas. Não que estas sejam inúteis: longe disso e nós somos os primeiros a utilizá-las. Mas pelo que elas oferecem: elas são fotografias dos comportamentos, descrições estruturais que não revelam seu significado sociológico e particularmente seu sentido, ou seja, a representação que os atores se fazem dos lugares ocupados por eles e pelos outros na relação. ${ }^{74}$

ANO $9 \quad 472 \quad 2 \circ$ SEMESTRE 
Dito de outra forma, a análise das transformações, das mobilidades masculinas, deve também integrar o ponto de vista subjetivo das pessoas, aqui os homens. Saber, então, medir o que são as relações entre homens e mulheres oferece um método de análise para compreender em parte as mudanças atuais. Mas como, nessa perspectiva, medir as mudanças entre homens, a tomada de distância de alguns com o nó central, homofóbico, heterossexista, das categorias de sexo? As análises feministas e pró-feministas, úteis para estudar as transformações positivas ou negativas das relações sociais de sexo, parecem não bastar. ${ }^{75}$

\section{O movimento queer}

É sem dúvida diante dessa dificuldade que apareceu ultimamente nos Estados Unidos, depois timidamente na França, ${ }^{76}$ a teoria queer. Leremos uma rápida apresentação no livro Nouvelles Approches des Hommes et du Masculin feita por Marie-Hélène Bourcier e a análise crítica dessa corrente realizada por Sylvie Tomolillo que vai ser publicada em breve.

Os ativistas queer se definem como anti-assimationistes e querem agrupar todos aqueles, e todas aquelas, que adotam as identidades sexuais e/ou identidades de gênero em diferença com as normas heterossexuais: gays, lésbicas, transgêneros, bissexuais... Todos contestando o próprio fato de serem colocados em categorias. Criticando ao mesmo tempo o binarismo homem/mulher e o heterossexismo da classificação dessas próprias categorias, a análise queer visibiliza uma parte das mudanças já realizadas. Basta escutar os transsexuais e o que eles/elas revelam de nossas classificações fixas, pesquisar em lugares de consumo sexual para se dar conta da ineficácia de nossas taxinomias. Para isso é necessário ir além do simples discurso dos homens recolhido das grandes pesquisas sobre sexualidade para ver $\mathrm{o}$ que realmente acontece na calçada. E também ultrapassar $O$ opróbrio moral, o estigma, ${ }^{77}$ que os coloca no grupo das pessoas prostituídas. Precisamos abandonar nossos laboratórios para estar mais perto das pessoas, de seus discursos e de suas práticas, o que não é a metodologia mais em voga nos estudos atuais sobre as sexualidades. Como lembrou um grande sociólogo no processo cheio de peripécias por que passei para poder me tornar orientador: ${ }^{78}$ "Estudar o comportamento de um ateliê de produção da indústria automobilística é, na sociologia, normal; aplicar o mesmo método para estudar militantes de extrema direita ou o adepto de uma seita é mais corajoso; seguir o mesmo caminho para as prostitutas ou troca de casais se torna escandaloso e suspeito de perversidade."

Pode-se imaginar que o termo, a palavra-imagem ou o conceito queer, afrancesado, se torne rapidamente federativo da desordem atualmente vigente nas análises críticas do masculino. Pierre Bourdieu ${ }^{79}$ observava que faltava ao movimento gay e lésbico um portavoz emblemático. Coloca-se então a falta de sinal, de uma bandeira, ${ }^{80}$ dos movimentos contestatórios da heteronormatividade, englobando em seu seio gays e lésbicas das novas gerações militantes, mas também o conjunto das pessoas que querem se situar fora desse binarismo sexual. Para que a gente se dê conta do eco que esse tipo de problemática tem para além as populações homossexuais, basta ver o grande público presente nas paradas gays e lésbicas na França, público que não pode ser reduzido à atratividade do comércio gay $^{81}$ ou ao movimento de apoio que o PaCS provocou.

\section{Uma mudança problemática}

A adoção de uma problemática crítica quanto ao duplo paradigma que estrutura o masculino propõe também uma renovação dos debates atuais nas ciências sociais ou em outros lugares. A consideração de uma análise não-heteronormativa abre os espaços de 
discussão, questiona nossos pressupostos sobre os homens e o masculino. No momento, nos textos que se querem progressistas e não-excludentes, aqueles que colocam em evidência um heterossexismo diferencialista, uma nota de pé de página nos informa que o autor considera que sua análise vale também para os/as homossexuais. ${ }^{82}$ Claro que eles/elas existem. Mas a questão não é tanto de visibilizar sua existência como integrar sua presença nas análises, questionar os pressupostos naturalistas que organizam sua invisibilização.

É assim quando se aborda a sexualidade masculina. Torna-se então impossível, integrando as diversas sexualidades que vivem os homens, pretender que a excitação se reduza à ereção, ou que o gozo seja sempre a ejaculação. Reintegrando formas de sexualidade em geral qualificadas de "passivas", não-penetrantes, a análise é obrigada a questionar o que esconde o discurso atual, como o discurso, dito sábio ou militante, que reproduz valores homofóbicos e sexistas. Mudar nossos paradigmas críticos, pelo menos aceitar que se juntem análises anti-sexistas e não heteronormativas, oferece instrumentos para desconstruir nossas representações unívocas, e muito freqüentemente uniformes, dos homens e do masculino. A escuta dos homens e das mulheres que hoje vivem, encenam ou sugerem outros tipos de sexualidade e de gênero ${ }^{83}$ contribui para isso.

\section{Notas}

1 Com o título original Pour une approche proféministe non homophobe des hommes et du masculin, publicado em Nouvelles Approches des Hommes et du Masculin, organizado por Daniel Welzer-Lang, Toulouse, Presses Universitaires du Mirail, 2000, p. 109-138. Tradução com autorização da editora.

${ }^{2}$ WELZER-LANG, 1999a. Para desenvolver meu ponto de vista, utilizarei em filigrana minhas sucessivas pesquisas. Eu agradeço a Sylvie Tomolillo, Jean-Yves Le Talec e Pascale Molinier pela releitura atenta deste trabalho. No original o autor diz "Habilitation à diriger des recherches". Esta é uma etapa da carreira universitária francesa que autoriza os professores universitários em início de carreira a orientarem teses de doutorado, que se compõem da apresentação do conjunto de publicações do candidato e de entrevista com um júri nacional (nota da tradutora).

${ }^{3}$ A rede européia de homens pró-feministas foi criada em 1996 (http:/www.europrofem.org). O sexto encontro da Universidade de verão euromediterrânea das homossexualidades se desenvolveu em julho de 1999 em Marseille.

${ }^{4}$ Ver também as análises de Michel Bozon (1998), François de Singly (1987, 1993, 1996, etc.), Pierre Bourdieu (1990, 1998), Jacques Comailles (1992), etc. A utilização do quadro da dominação masculina, ou das relações sociais de sexo por homens-sociólogos, já antiga para alguns autores como Maurice Godelier e François de Singly, foi, às vezes, denunciada por sociólogas feministas como constitutiva de um novo desafio do trabalho realizado por sociólogas feministas (DEVREUX, 1995). Quanto aos trabalhos de Bourdieu, podem ser lidas com grande interesse as críticas recentes (MATHIEU, 1999; LOUIS, 1999). Da minha parte, trato as relações entre os homens e as relações sociais de sexo em um outro artigo publicado (WELZER-LANG, 2000).

${ }^{5}$ Particularmente os trabalhos realizados pelo APRE (Atelier Produção-Reproducão), que se reuniu de 1985 a 1987, dando seqüência a um primeiro trabalho coletivo (COLLECTIF, 1984), e as análises do ATP "Mulheres, Feminismo, Pesquisa" (HURTIG, KAlL \& ROUCH, 1991).

${ }^{\circ} \mathrm{O}$ que aparece, no entanto, ainda na análise rígida de Pierre Bourdieu (1998).

${ }^{7}$ Ver em particular, o importante trabalho realizado atualmente pelo grupo de pesquisa MAGE - Marché de Travail et Genre (Mercado de Trabalho et Gênero) no domínio do trabalho assalariado.

${ }^{8}$ Penso particularmente nas análises de Nicole-Claude Mathieu $(1985,1991)$ sobre os efeitos diferenciados que produz a dominação masculina sobre a consciência, a percepção e o conhecimento do social; nos textos de Maurice Godelier $(1982,1995)$ que mostram como a dominação masculina está subentendida por segredos coletivos que dividem os dominantes, segredos que para alguns deles, entre Baruya que ele estuda, não devem ser revelados às mulheres, sob pena de morte.

9 Uma das conquistas de meus trabalhos diz respeito à dupla definição dos fatos sociais, o "duplo standart assimétrico". Assim, eu mostrei, graças à análise de algumas centenas de testemunhos detalhados (WELZERLANG, 1988, 1991,1992), que não apenas os homens violentos e as mulheres violentadas nem sempre falam da mesma coisa quando elas/eles enunciam as violências, mas que, além disso, a partir do momento em que eles abandonam a posição de negação, atitude defensiva inicial, os homens violentos podem 
definir mais violências que suas companheiras. Dito de outra forma, nossas categorias de definição da violência são também pré-noções que se deve desconstruir. Os homens violentos definem a violência que eles exercem sobre sua companheira como um continuum de violencia física, psicológica, verbal, sexual, associada a uma intenção: intenção de dizer, de exprimir um sentimento, um desejo ou uma vontade. "Era para Ihe dizer.. Ihe mostrar", eles dizem. Quanto às mulheres violentadas - pelo menos aquelas que não foram conscientizadas pela intervenção feminista - elas definem a violência como um discontinuum essencialmente composto por violência física. As violências físicas são definidas de maneira restritiva, como golpes dados com a mão ou com o pulso fechado (até com o pé), associados à intenção de fazêlas sofrer. Eu recolhi múltiplos exemplos de cenas qualificadas pelo homem de violência, cenas onde a mulher, a partir de lamentos feitos por seu companheiro, ou da invocação de desculpas (a perda de controle, o álcool, o acaso, o ato fortuito), desqualifica os golpes recebidos para defini-los como "coisas duras, atos dolorosos", mas não violências. As violências domésticas são assim definidas de forma mais abrangente por aqueles que as controlam e as praticam do que por aquelas que as sofrem. Eu chamei isso de "binômio da violência doméstica".

Da mesma forma, com Jean-Paul Filiod (WELZER-LANG \& FILIOD, 1994), nós mostramos que a meia jogada pelo chão aparece num casal também como ausência de um espaço apropriado para o homem "normal" na casa. São os sinais impressionantes mas tangíveis das relações sociais de sexo atuais. Foi fácil para nós mostrar, no que se refere à questão da limpeza e da arrumação, que homens e mulheres seguem duas lógicas simbólicas diferentes. As mulheres, por preocupação de serem reconhecidas como boas esposas e boas mães, por pressão das pessoas que as cercam e das normas, limpam antes que não estejam (muito) sujas. As mulheres são associadas, em seu interior psíquico, à limpeza (e à arrumação, o que dá no mesmo) do espaço doméstico. Quando está sujo na casa delas, são elas que estão sujas de alguma maneira. Para os homens, pelo menos para aqueles que fazem o trabalho doméstico, aqueles que se habituaram a não perturbar quando se ensinava a suas irmãs a limpar, estes limpam quando vêem que está sujo. Cada um/uma tendo seu limite. As mulheres são preventivas e os homens são curativos. Ao menos nas construções sociais habituais ligadas à dominação. Trata-se apenas, evidentemente, de construções sociais. E não é porque as estudantes ou as jornalistas me mostram às vezes a desordem de seu interior para significar que elas não são mulheres submissas, que esta análise não sirva.

Poderíamos multiplicar os exemplos dessa dupla construção de representações e práticas sociais. Assim, no estudo sobre troca de casais, as casas noturnas de suruba e a prevenção da AIDS, nós mostramos facilmente como nosso erotismo está construído diferentemente e as conseqüências que isso produz sobre a (re)negociação das formas eróticas comuns; particularmente como as mulheres são levadas a se submeter ao erotismo pornográfico masculino.

É um verdadeiro problema epistemológico no estudo das relações entre gêneros. O/a pesquisador/a deve aceitar como postulado que não apenas nossas informações sobre as formas de dominação são diferentes, mas que, além disso, eles/elas devem tirar conseqüências científicas. Não mais pesquisar o que faz a diferença entre os sexos, mas descrever e compreender como a diferença se constrói socialmente para ocultar as relações sociais de sexo.

${ }^{10}$ Alguns, como Bourdieu, continuam a pensá-las inicialmente como simbólicas, quando os trabalhos das mulheres feministas intelectuais ou militantes e os trabalhos que estudaram estas questões, entre os quais os meus (WELZER-LANG, 1988, 1991, 1992, 1999), mostram como, mesmo sem falar da violência econômica que limita a autonomia das mulheres, a violência física está presente cotidianamente - particualrmente através do medo de que ela se (re)produza - e se torna assim um verdadeiro freio à autonomia das mulheres.

1 Particularmente para determinar quem do sexo ao gênero, precede ao outro e/ou quais análises sociológicas e politicas sub-jazem as representações das relações entre sexo e gênero. Ver a respeito os escritos de Christine Delphy $(1991,1998)$ e Nicole-Claude Mathieu $(1989 ; 1991)$.

${ }^{12}$ Será que é necessário validar a hipótese de um backlash generalizado (FALUDI, 1993), ou pensar, como postulam Anne-Marie Devreux e Huguette Dagenais, que a mudança social é "seguida, e mesmo muito seguida (sublinhado por mim) por um agravamento da situação dos dominados e oprimidos" (DAGENAIS \& DEVREUX, 1998, p. 3)?

${ }^{13}$ Os textos dessas autoras que servem de base hoje à análise feminista estão novamente disponíveis e reunidos em obras: MATHIEU (1991), GUILLAUMIN (1992), DELPHY (1998), TABET (1998). Sua leitura constitui um preâmbulo para quem quiser adquirir os fundamentos da desconstrução feminista.

${ }^{14}$ O conceito de patriarcado, definido por Delphy em 1970, que foi retomado de forma ampla pelo movimento social (feminismo, antisexismo...) é problemático. Particularmente, quando se trabalha sobre os homens, o que não era o propósito de Delphy. Em sua acepção de senso comum, o termo tirado da antropologia conota o poder dos pais (dos patriarcas) sobre as mulheres e as crianças. Apesar de pretender ser um conceito descritivo da dominação masculina, ele sofre, por não dar o devido valor às mudanças nas relações sociais de sexo e, em particular, às modificações se referem às relações de poder (o direito de 
guarda, dado às mães, por exemplo) e de apropriação das crianças. Ora, nesse campo - e é isso que fundamenta as críticas dos movimentos reacionários de pais divorciados, como o Movimento pela Condição Masculina - os anos 1980-90 viram as leis se modificarem em detrimento do poder patriarcal (ver THÉRY, 1998). De minha parte, eu há muito tempo prefiro, e utilizo, o termo viriarcado proposto por Nicole-Claude Mathieu (1985), que ela define como o poder dos homens, sejam eles pais ou não, que as sociedades sejam patrilineares, patrilocais ou não. Christine Delphy, continuando sua reflexão de 1984, voltou a esse conceito em 1998, na introdução do primeiro tomo de seus escritos, esclarecendo: "Desde 1970, eu utilizei o termo "patriarcado. [...] Se usei um termo aparentemente tão vago, é porque, apesar disso, me parecia, e me parece ainda, o mais apropriado para denotar um conjunto que toca todos os aspectos da realidade. Eu queria marcar desde o início uma premissa fundamental de meu trabalho: que a opressão das mulheres constitui um sistema. Mas qual sistema? Aí está toda a questão. É necessário preencher esta noção e isso só se faz pouco a pouco. [...] No entanto, eu, ao utilizá-lo, acabei restringido a acepção do termo. Para muitos, o termo patriarcado é sinônimo de "subordinação das mulheres". Para mim também, com esta nuance: eu acrescento as palavras "aqui" e "agora", que fazem toda a diferença. Quando eu escuto, o que acontece seguido, que "o patriarcado se modificou entre a idade da pedra e 1950", eu sei que não se trata de "meu" patriarcado. Eu estudo não uma entidade a-histórica que passearia através dos séculos, mas as sociedades industriais contemporâneas (1998, p. 17-18).

${ }^{15}$ Ou dos homens que cuidam das crianças pequenas.

${ }^{16}$ Que podemos definir como relações sociais entre as pessoas de mesmo sexo, ou seja, as relações entre homens ou as relações entre mulheres.

17 GODELIER (1982).

${ }^{18}$ Nos Baruya, a casa dos homens está materializada e localizada num lugar específico. Para uma melhor leitura, eu escrevo "casa-dos-homens" para metaforizar os lugares da socialização masculina em nossas sociedades complexas.

19 "O segundo segredo, mais sagrado ainda pois este não pode ser conhecido por nenhuma mulher, é que o esperma dá aos homens o poder de fazer renascer os meninos fora do ventre de sua mãe, fora do mundo masculino, no mundo dos homens e apenas através deles. Este segredo, que é o mais sagrado, é que os jovens iniciados, desde que eles penetram na casa dos homens, são alimentados do esperma dos mais velhos, e que esta ingestão é repetida durante vários anos com o objetivo de fazê-los crescer mais e mais fortes que as mulheres, superiores a elas, aptos a dominá-las, a dirigi-las" (p. 91-92). Encontrar-se-ão outros exemplos etnográficos em importante trabalho de Churchill (sem referência). Assinalemos que as primeiras observações de etnólogos sobre este tema datam de 1906 (Westermarck, sem referência).

${ }^{20} \mathrm{Em}$ alguns grupos masculinos, em volta de uma bola ou de um bastão de hockey, aparecem agora algumas mulheres. Tendo observado essas meninas que os pais qualificam de "garçons manqués", tudo parece sugerir que elas também, no momento, desejam ter acesso ao status de rapaz, de cara... É necessário esperar que o futuro nos traga informações sobre os efeitos de uma verdadeira mixidade nessas aprendizagens na evolução da homofobia ao status de virilidade.

${ }^{21}$ Em alguns casos, raros, se trata das calças dos pais. O que não muda em nada a análise. Na educação, pai e mãe não são posições simbólicas. Quando a educação apresenta sinais de atipismo, de exceção em relação aos modelos habituais, outros mecanismos agem para confortar as crianças nos modelos ditos normais da paternidade e da maternidade.

${ }^{22}$ No Québec, em 1984, um comitê sobre as infrações sexuais contra crianças e jovens assinalava que, ao lado do número extremamente limitado de queixas de estupros de homens, um estudo canadense mostra que uma mulher sobre duas e um homem sobre três reconheciam ter sido vítimas de atos sexuais não desejados ( $42,1 \%$ das pessoas no Canadá e $40,2 \%$ no Québec). A maior parte das pessoas tinha sido agredida durante sua infância ou sua adolescência (BADGLEY, 1984). Para uma discussão dos dados franceses, não contraditórios com o estudo do Québec, remeto a meu texto sobre homofobia (1994).

${ }^{23}$ WELZER-LANG, MATHIEU \& FAURE (1996).

${ }^{24} \mathrm{Ou}$, mais exatamente, durante um tempo mais ou menos longo, dependendo da capacidade de os escutar e de lhes devolver a justiça. Todo homem abusado é culpabilizado e se torna responsável pelo que viveu. Ele foi incapaz de se defender. Ele fracassou diante da primeira regra dos homens, que exige que não se deve dar, ou se deixar comer. Além dos traumatismos físicos, a vergonha é grande de ser sido pego na armadilha, de ter sido pego "como uma mulher".

${ }^{25}$ Seria necessário falar mais exatamente de abusos sexuados. Quer dizer, de abusos que se referem à dominação de sexos e a suas construções sociais. Para as vítimas de estupro, a agressão é raramente sexual. Mesmo tendo ouvido de alguns homens me dizerem que o primeiro abuso vivido foi o que lhes revelou sua homossexualidade, os mesmos são unânimes em dizer que eles teriam preferido ser iniciados de outra forma. E mais, por causa do abuso, alguns se proíbem durante um tempo mais ou menos longo de aceitar seus desejos sexuais por outros homens.

${ }^{26}$ Não esqueçamos que nossas informações sobre essa forma particular de abuso são relativamente recentes. 
${ }^{27}$ DEJOURS, 1998; 2000.

${ }^{28}$ Novamente aqui o fetichismo fálico da virilidade.

${ }^{29}$ Idealmente, na ideologia masculina, deve-se poder se apropriar das mulheres respeitando a injunção que diz que "não se deve bater numa mulher nem com uma flor". O charme e a sedução natural do macho superior deveriam bastar. Mesmo se essa "sedução" pode também ser um assédio mais ou menos forte.

${ }^{30}$ No original "racketé" (nota da tradutora).

${ }^{31}$ DELPHY, 1970; GUILLAUMIN, 1978.

32 WELZER-LANG, 1998a; 1998b.

${ }^{33}$ Nós estamos realizando atualmente uma pesquisa sobre o "tráfico" de mulheres feito pelos legionários. A legião estrangeira é um corpo de elite do exército francês composto apenas por soldados não-franceses (nota da tradutora).

${ }^{34}$ A pesquisa que define o quadro exato desses privilégios ainda não está pronta.

${ }_{35}$ Descobri também (segredo dos segredos) que algumas "mulheres" têm um "pênis entre as pernas", dito por um de meus informantes (um legionário homossexual).

${ }^{36}$ No texto, RMIste, que significa indivíduo desempregado que recebe renda mínima do governo (nota da tradutora).

${ }^{37}$ Ver sobre isso o excelente artigo de Christine Delphy de 1991.

${ }^{38}$ FOUCAULT, 1976; 1984.

${ }^{39}$ ARIÈS, 1973.

${ }^{40}$ FLANDRIN, 1981; 1982; 1984.

${ }^{41}$ LE TALEC, 2000.

${ }^{42}$ FOUCAULT, 1976.

${ }^{43}$ Essa análise sobre a performatividade do modelo heterossexual deve ser modulada para as mulheres. $O$ quadro heterossexual que lhes é também imposto se conjuga a uma atração masculina pelos amores sáficos, desde que sob controle, haja vista o número de vídeos pornográficos que mostram cenas - para os homens espectadores - de lésbicas. Estes vídeos estão de acordo com os critérios masculinos e homofóbicos do erotismo.

${ }^{44}$ Esta definição, publicada em 1994, é uma adaptação (livre) da proposta por Joseph Neisen (1990).

${ }^{45}$ WELZER-LANG, 1988.

${ }^{46}$ POLLACK, 1998.

${ }^{47} \mathrm{~A}$ gente subestima freqüentemente as representações ligadas ao heterossexismo. Assim, na organização dos dirigentes de uma grande associação humanitária sobre a sexualidade ligada à AIDS, um dos médicos responsáveis falava com desenvoltura da atração erótica que exercia sobre ele a sodomia de uma mulher, e ao mesmo tempo explicava que as relações anais entre homens eram "contra a natureza e, sobretudo, sujas e repugnantes".

${ }^{48}$ Que ela seja qualificada de patológica, criminal, desviante, segundo o registro dito científico, e sempre heteronormativo, que as avalia.

${ }^{49}$ HAICAULT, 1992.

${ }^{50}$ Este heterossexismo diferencialista produz também, às vezes, "homofobia diferencialista" quando, por exemplo, se admite que os/as homossexuais (ou outros grupos específicos) têm qualidades coletivas e individuais (sensiblidade, gosto, etc.) um pouco diferentes dos homens e das mulheres normais.

${ }^{51}$ A capacidade jurídica e social para homens e mulheres homossexuais de pôr no mundo e/ou criar crianças. ${ }^{52}$ TABET, 1985.

${ }^{53}$ Observemos também as variantes culturalistas de Irene Thery, para quem o casal é, na França, culturalmente heterossexual. $\mathrm{O}$ que dá no mesmo: negar o direito à paternidade aos pais do mesmo sexo. Ver a este respeito a revista Le Banquet, 1998, n. 12 e 13.

54Sobre a história recente dos grupos masculinos criticando o sexismo, faço referência a meu artigo em Temps Modernes (WELZER-LANG, 1997).

${ }^{55}$ Este termo adotado pelos grupos de homens franceses progressistas nos anos 80 não tinha, na época, sua conotação revanchista e reacionária que existe atualmente.

${ }^{56}$ Star:s/CMAB, 44 rue Burdeau, 69001 Lyon.

${ }^{57}$ Antes de 1981, a maioridade sexual ocorria mais tarde no caso das relações homossexuais.

${ }^{58}$ Exceção notável: a revista Star, que estabelece relações entre feminismo e lutas contra a homofobia: "Hetero ou homo, não aos bairros para os machos." Star volta-se cada vez mais para uma crítica queer das identidades de gênero: "Nós somos queers porque não somos heteros, mas bissexuais, lésbicas, gays, travestis, transexuais...", diz o cartaz publicado em 1994. Existem também as associações como o MFPF (Movimento Francês pelo Planejamento Familiar), que, há muito tempo integra, sob uma forma ou outra, lutas feministas e análises antidiscriminatórias sobre as homossexualidades.

${ }^{59}$ LIPIETZ, 2000.

${ }^{60}$ Ver a nota número 9. 
${ }^{61}$ BALANDIER, 1988

${ }^{62}$ Nós definimos aqui como transgenders, "transgêneros", os prostitutos homens de nascimento que se prostituem enquanto mulheres. Em nossa pesquisa, em 1992 em Lyon, com Odette Barbosa e Lilian Mathieu, eles representavam uma mulher sobre três (o número é praticamente o mesmo em outras grandes cidades européias), mas sobretudo eles captavam uma grande parte dos clientes, que no entanto se apresentam aos pesquisadores/as como heterossexuais.

${ }^{63} \mathrm{O}$ que, observemos, não é novo: Jacques Revel (1984) dá alguns exemplos históricos disso.

${ }^{64} \mathrm{Minitel}$ é um sistema eletrônico exclusivamente francês de comunicação, anterior à internet e com algumas características similares a esta. O minitel rose é um serviço pago de acesso a serviços e mensagens sexuais (nota da tradutora).

${ }^{65} \mathrm{O}$ que corresponde na França e no Québec aos homens que aderem à Rede Homens-Québec ou à Rede Homens-França criadas por Guy Corneau. Quer dizer: homens que utilizam os grupos de palavra e/ou de terapia para viver melhor suas masculinidades e suas relações com as mulheres.

${ }^{66}$ SINGLY, 1993.

${ }^{67}$ SINGLY, 1993, p. 59.

${ }^{68}$ No original "Une vieille lune" (nota da tradutora).

${ }^{69}$ SINGLY, 1993, p. 59.

${ }^{70}$ RAYMOND, 1981.

${ }^{11}$ Veja-se a dificuldade para a aceitação do termo lesbofobia.

${ }^{72}$ MATHIEU, 1994.

${ }^{73}$ DAUNE-RICHARD \& DEVREUX, 1990.

${ }^{74}$ DAUNE-RICHARD \& DEVREUX, 1990, p. 126-127. Sublinhado por mim.

${ }^{75}$ Mesmo que, particularmente nas relações entre sexo e gênero, nós disponhamos de instrumentos, e de artigos excepcionais, particularmente as análises de Nicole-Claude Mathieu (1989; 1994).

${ }^{76}$ As Brigadas-Rosa, as Frações do Exército Rosa, Os Corações do Exército Rosa, a revista Androzine e sobretudo a revista Star (Lyon) são alguns exemplos do lado dos militantes; o seminário ZOO, em Paris, desenvolveu desde 1997 (BOURCIER, sem referência) análises queer. Em Toulouse, ocorreram vários debates sobre esse tema, particularmente na pesquisa sobre as Irmãs da Perpétua Indulgência, feita por Sylvie Tomolillo e Jean-Yves Le Talec.

77 PHETERSON, 1992.

${ }^{78}$ No original "Passage de mon Habilitation" (nota da tradutora).

${ }^{79}$ BOURDIEU, 1997.

${ }^{80} \mathrm{O}$ que, observemos, vai contra a própria vontade dos ativistas queer americanos/as, que nunca quiseram que o termo queer se tornasse uma bandeira, um emblema.

${ }^{81}$ Apesar de os comércios da noite serem centrais entre os estabelecimentos gays, já que eles representam uma forma de integração do modo de vida homossexual na população geral, particularmente entre os jovens.

${ }_{82} \mathrm{O}$ método é conhecido. Ele é freqüentemente utilizado pelos/as autores/as que se recusam a feminilizar seus textos e se contentam em dizer que, mesmo escrito no masculino, seu texto integra também as mulheres.

${ }^{83}$ Eu penso naqueles e naquelas que falsificam ou tiram do lugar os atributos do gênero, mostrando de fato sua não-naturalidade (PRECIADO, 2000).

\section{Referências bibliográficas}

ALTMAN, Dennis. Homosexual Oppression and Liberation. New York: New York University Press, 1993. [première édition, 1971].

ARIÈS, Philippe. L'enfant et la vie familiale sous l'Ancien Régime. Paris: Éd. du Seuil, 1973.

BADGLEY, Robin et al. Infractions sexuelles à l'égard des enfants, rapport du Comité sur les infractions sexuelles à l'égard des enfants et des jeunes, Ottawa, Approvionnement et Services, 1984. vol I et II.

BALANDIER, Georges. Le désordre. Paris: Fayard, 1988.

BOURDIEU, Pierre. "La domination masculine". Actes de la Recherche en Sciences Sociales, n. 84, p. 2-31, 1990.

. "Quelques questions sur la question gay et lesbienne", Liber, n. 3, p. 7-8, 1997. 
. "Quelques questions sur la question gay et lesbienne" In: ERIBON, Didier (sour la dir.). Les études gays et lesbiennes. Actes du Colloque du Centre Georges Pompidou, 23 et 27 juin 1997. Paris: Éd. du Centre Georges Pompidou, 1998. p. 45-50.

. La domination masculine. Paris: Seuil, 1998. (coll. Liber).

BOZON, Michel."Amour, désir et durée. Cycle de la sexualité conjugale et rapports entre hommes et femmes". In: BAJOS, Nathalie; BOZON, Michel; FERRAND, Alexis; GIAMI, Alain; SPIRA, Alfred; et le groupe ACSF (sour la dir.). La sexualité aux temps du sida, Paris: PUF, 1998. p. 175-252.

COLLECTIF. Le sexe du travail. Structures familiales et système productif. Grenoble: Presses Universitaires de Grenoble, 1984.

COMMAILLE, Jacques. Les stratégies des femmes, travail, famille et politique. Paris: La Découverte, 1992.

DAUNE-RICHARD, Anne-Marie; DEVREUX Anne-Marie. La reproduction des rapports sociaux de sexe. A propos des rapports sociaux de sexe: parcours èpistémologiques, Rapport pour l' A . T. P. CNRS, 1990, tome 3. [première édition 1986].

DAGENAIS, Huguette; DEVREUX, Ann-Marie. "Les hommes, les rapports sociaux et le féminisme: des avancées sous le signe de l'ambigüité". In: DAGENAIS, H.; DEVREUX, A-M (sous la direction). Ils changent disent-ils, Nouvelles Questions Féministes, v. 19, n. 2-3-4 et Recherches Féministes, v. 11, n. 2, p. 1-22, 1998.

DEFERT, Daniel. "L'enjeu des gais - L'homosexualisation du sida". Gai Pied Hebdo, n. 446, p. 60-63, 29 novembre 1990.

DEJOURS, Christophe. Souffrance en France, la banalisation de l' injustice Sociale. Paris: Seuil, 1998.

. "Le masculin entre sociéte et séxualité". In: WEZER-LANG, Daniel. Nouvelles Approches des hommes et du masculin. Toulouse, Presses Universitaires du Mirail, 2000.

DELPHY, Christine. "L' ennemi principal". Partisans, n. spécial , Libération des femmes, année zéro, juillet-août, n. 54-55, p. 57-172, 1970.

. "Penser le genre". In: HURTIG, Marie-Claude; KAIL, Michèle; ROUCH, Helène (sous la dir.). Sexe et genre, de la hiérarchie entre les sexes. Paris: Éd. CNRS, 1991. p. 89-107.

. "L' ennemi principal". In: L' ennemi principal; tome 1: Economie politique du patriarcat. Paris: Syllepse, 1998. p. 31-56.

DEVREUX, Anne-Marie. "Sociologie généraliste et sociologie féministe: les rapports sociaux de sexe dans le champ professionnel de la sociologie". Nouvelles Questions Féministes, v. 16, n. 1, p. 83-110, 1995.

FALUDI, Susan. Backlash, La guerre froide contre les femmes. Paris: Éd. des femmes, 1993.

FLANDRIN, Jean-Louis. Le sexe et l' occident. Paris: Seuil, 1981.

. "La vie sexuelle des gens mariés dans l'ancienne société: de la doctrine de l'église à la réalité des comportements". In: ARIES, P.; BÉJIN, A. (sous la dir.). Communication, n. 35, Sexualités occidentales, Paris: Seuil, 1982.

. Familles, parenté, maison, sexualité dans l'ancienne Societé. Paris: Seuil, 1984.

FOUCAULT, Michel. Histoire de la sexualité; tome 1: La volonté de savoir. Paris: Gallimard, 1976.

. Histoire de la sexualité; tome 2: L' usage des plaisirs. Paris: Gallimard, 1984a.

. Histoire de la sexualité; tome 3: Le souci de soi. Paris: Gallimard, 1984b.

GODELIER, Maurice. La production des Grands Hommes. Paris: Fayard, 1982. [réédition en 1996].

. "Du quadruple rapport entre les catégories de masculin et de féminin". In: EPHESIA, La place des femmes, les enjeux de l'égalite au regard des sciences sociales. Paris: La Découverte, 1995. p. 439-442. 
GUILLAUMIN, Colette. "Pratiques de pouvoir et idée de nature (2). Le discours de la nature". Questions féministes, n. 3, p. 5-28, 1978. [réédité em 1992 dans Sexe, race et pratiques du pouvoir, Paris: Côté femmes]. . Sexe, race et pratiques du pouvoir. Paris: Côté femmes, 1992.

HAICAULT, Monique. "Le symbolique dans la complexité des rapports sociaux de sexe: le travail de la doxa". In: Actes du XIVe Congrès de l'AISLF, Groupe de travail sociologie des rapports sociaux de sexe, Toulouse/Aix-en-Provence, ns, 1992.

HURTIG, Marie-Claude; KAIL, Michèle; ROUCH, Hélène (sour la dir.). Sexe, et genre, de la hiérarchie entre les sexes. Paris: Éditions du CNRS, 1991.

LE TALEC, Jean Yves. “L'éveil d'une nouvelle 'conscience gaie'. Liens entre la problématique proféministe et la question gaie". In: Nouvelles approches des hommes et du masculin,... 2000. p. 141-162.

LIPIETZ, Alain. "L'homme politique, loup pour la femme". In: Nouvelles approches des hommes et du masculin.Toulouse, Presses Universitaires du Mirail, 2000. p. 305-312.

LOUIS, Marie-Victoire. "Bourdieu, défense et illustration de la domination masculine". Les temps modernes, n. 604, p. 325-358, 1999.

MATHIEU, Nicole-Claude. "Quand céder n'est pas consentir, des déterminants matériels et psychiques de la conscience dominée des femmes, et des quelques-unes de leurs interprétations en ethnologie". In: L' Arraisonnement des Femmes, essais en anthropologie des sexes. Paris: EHESS, 1985. p. 169-245.

. "Identité sexuelle/sexuée/ de sexe. Trois modes de conceptualisation du rapport entre sexe et genre". In: DAUNE-RICHARD; HURTIG; PICHEVIN (sous la dir.). Catégorisation de sexe et constructions Scientifiques. Aix-en-Provence: Université de Provence, CEFUP, 1989. p. 109-147.

. L'anatomie politique, catégorisations et idéologies du sexe. Paris: Côté-femmes, 1991.

. "Dérive du genre, stabilité des sexes". In: DION, Michels (sous la dir.). Madonna, érotisme et pouvoir. Paris: Seuil, 1994. p. 54-70.

. "Bourdieu ou le pouvoir auto-hypnotique de la domination masculine". Les temps modernes, n. 604, p. 296-324, 1999.

MOLINIER, Pascale. "Autonomie morale subjective et construction de l'identité sexuelle: l'apport de la psychodynamique du travail". Revue Internacionale de Psychologie, v. III, n. 5, p. 53-62, 1997.

NEISEN Joseph. "Heterosexism or Homophobia? The Power of the Language We Use". Outlook, n. 10, p. 36-37, 1990.

PHETERSON, Gail. "La catégorie "prostituée" dans la recherche scientifique". In: Collectif, La prostitution, quarante ans aprés la conventions de New York, Ecole des sciences criminologiques Léon Cornil. Bruxelles: Bruyllant, 1992. p. 373-386.

POLLAK, Michaël. Les homosexuels et le SIDA, Sociologie d'une épidémie. Paris: Métaillé, 1988. p. 44.

PRECIADO, Beatriz. Manifeste Contra-sexuel. Paris: Balland, 2000.

RAYMOND, Janice. L'empire transexuel. Paris: Seuil, 1981.

REVEL, Jacques. "Masculin/Féminin: sur l'usage historiographique des rôles Sexuels". In: PERROT, Michelle (sous la dir.). Une histoire des femmes est-elle possible? Paris: Éd. Rivages, 1984. p. 121-140.

SINGLY (de) François. "Théorie critique de l'homogamie". L'année sociologique, n. 37, p. 181-205, 1987.

. "Les habits neufs de la domination masculine". Esprit, n. 11, p. 54-64, 1993.

. Le soi, le couple et la famille. Paris: Nathan, 1996. (coll. Essais et Recherche).

ANO $9 \quad 480 \quad 2 \circ$ SEMESTRE 
. "Conclusions". In: Conseil de l'Europe. Promouvoir l'égalité: un défi commun aux hommes et aux femmes. Actes du séminaire international de Strasbourg, p. 77-86, 1718 juin 1997.

TABET, Paola. "Fertilité naturelle, reproduction forcée". In: L'Arraisonnement des Femmes, essais en anthropologie des sexes. Paris: EHESS, 1985. p. 61-146.

. La construction sociale des inégalités des sexes, Des outils et des corps. Paris: L'Harmattan, Bibliothèque du féminisme, 1998.

THÉRY, Irène. Couple, filiation et parenté aujourd'hui, le droit face aux mutations de la famille et la vie privée, Rapport à la ministre de l'Emploi et de la Solidarité et au Garde des Sceaux, Ministre de la Justice. Paris: Odile Jacob, Documentation française, 1998.

WELZER-LANG, Daniel. Le viol au masculin. Paris: L' Harmattan, 1988. . Les hommes violents. Paris: Lierre et Coudrier, 1991.

. Arrêté, tu me fais mal... La violence domestique 60 questions, 59 réponses. Montreal et Paris: Éd. Le Jour, V.L.B, 1992.

. "Les hommes: une longue marche vers l'autonomie". Les temps moderns, n. 593, p. 199-218, avril-mai 1997.

. Entre commerce du sexe et utopies. Actes du premier séminaire européen sur l'échangisme, départements de sociologie des universités de Tolouse-Le Mirail et Barcelone et département d'anthropologie sociale et de philosophie de l'universitat Rovira i Virgili à Tarragone. Toulouse: Les Traboules, 1998a.

. "La "planète échangiste" à travers ses petites Annonces". Panoramiques, Le coeur, le sexe et toi et moi..., p. 111-123, 1998b.

. Et les hommes? Etudier les hommes pour comprendre les changements des rapports sociaux de sexe. Université Toulouse - Le Mirail, dossier d'Habilitation à diriger les recherches, 1999a.

. "Travailler ensemble entre hommes et femmes: émergence de la question et questions de méthodes". In: DAGENAIS, H.; DEVREUX , A-M. (sour la dir.). Ils changent disent-ils, numéro commun, Nouvelles Questions Féministes (France) et Recherche féministe (Québec), v. 19, n. 2-3-4, v. 11, n. 2, p. 71-100, 1999 b.

. "Les hommes et les rapports sociaux de sexe, où est le problème?" UTINAM, numéro spécial Le genre: de la catégorisation du sexe, coordonée par Nick Le Freuvre, à paraître, 2000.

WELZER-LANG, Daniel; BARBOSA, Odette; MATHIEU, Lilian. Prostitution, les uns, les unes, et les autres. Paris: Métalié, 1994.

WELZER-LANG, Daniel ; DUTEY, Pierre; DORAIS, Michel. La peur de L'autre en soi, du sexisme à la homophobie. Montréal: V. L. B. Editeur, 1994.

WELZER-LANG, Daniel; FILIOD Jean Paul (sous la dir.). Des hommes et du masculin. CEFUPCREA, Lyon: Presses Universitaires de Lyon, 1994. p. 7-11.

WELZER-LANG, Daniel; MATHIEU, Lilian; FAURE, Michäel. Séxualités et violences en prison, ces abus qu' on dit sexuel en milieu carcéral. Observatoire International des Prisons, Lyon: Éditions Aléas, 1996. 
The Construction of the Masculine: Women's Domination and Homophobla

Abstract: This article interrogates the theoretical frameworks, methods and instruments of analyses employed in the study of men and masculinity. In doing so, it questions essentialist definitions of men while examining the schemes, the habitus, and the homophobic, heterosexual and virile model that construct and strengthen masculine identity and domination. To accomplish the above, the author addresses a vast array of contemporary French feminist debates.

Keywords: masculinity, homophobia, domination, French feminist theory.

Tradução de Miriam Pillar Grossi Revisão de Helena Heloísa Fava Tornquist

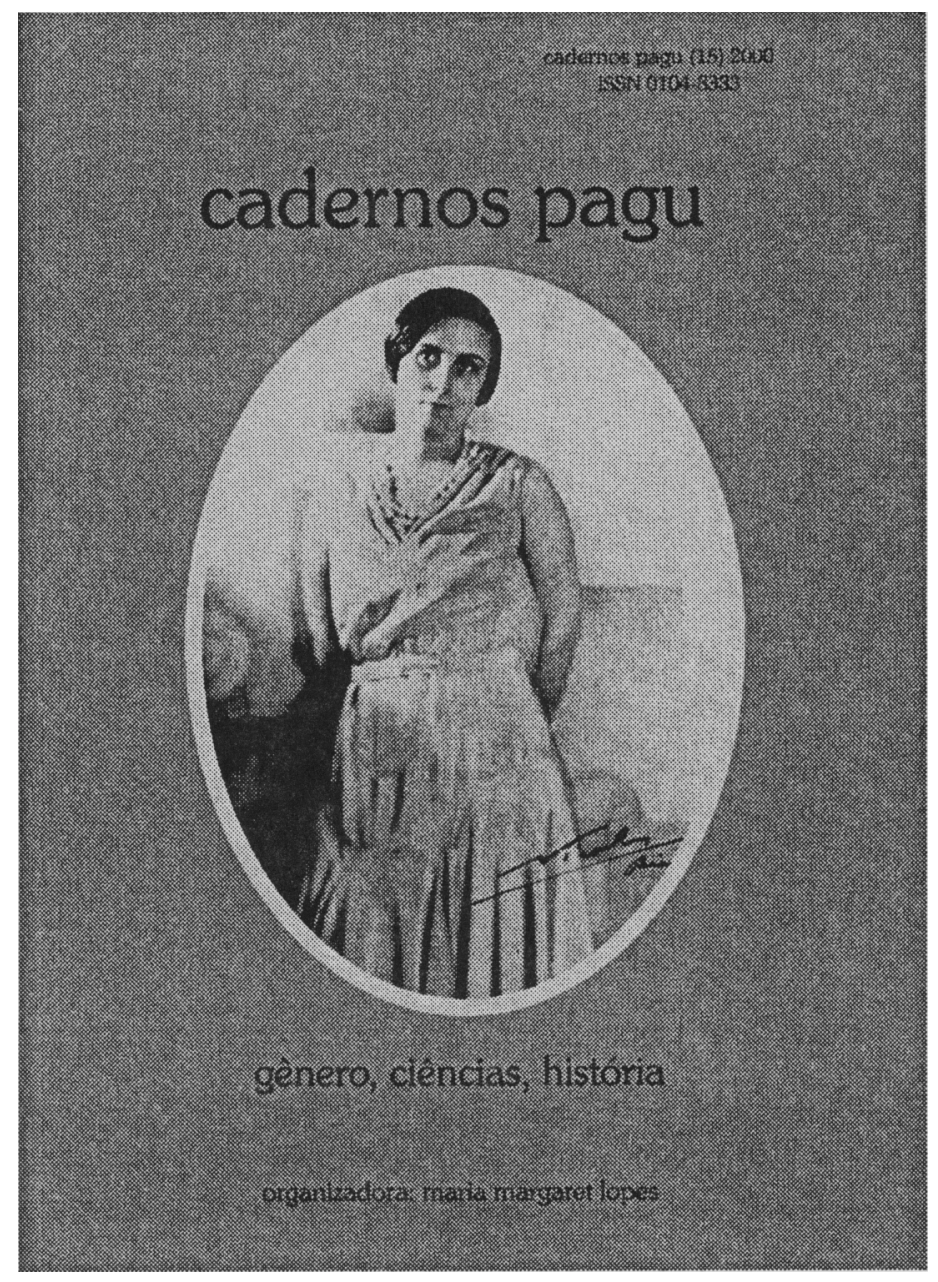

